\title{
Callose in compression wood tracheids
}

\author{
P. BRODZKI
}

\author{
Department of Plant Anatomy and Cytology \\ University of Wroclaw, ul. Kanonia 6, Wroclaw, Poland
}

(Received: 13 May, 1971.)

\begin{abstract}
A study of 20 gymnospermous species has shown that in most of them callose occurs in the helical checks of the S2 layer of cell walls in the compression wood tracheids. It is suggested that owing to its swelling properties callose plays a part in the longitudinal extension of compression wood.
\end{abstract}

\section{INTRODUCTION}

In the compression wood of gymnosperms longitudinal stresses operate. In many experiments it has been shown that compression wood remains in a state of compression and exhibits a tendency to extend (M ü nch 1938; Wardrop 1965; Hejn owicz 1967). Since compression wood is localized on the lower side of branches, its extension results in an upward bending of the branches and their maintenance at a genetically determined position in spite of gravitation.

The existence of longitudinal stresses in the stem containing the compression wood may be demonstrated after removing a part of normal wood so that the remaining normal and compression wood bend like bi-metal. It has been shown that compression wood contracts during drying to a much greater extent than normal wood and returns to its original length when moistened.

In the S2 layer of compression tracheids walls helical checks occur, described by Core et al. (1961) and by Côté (1965). These authors believe, that strong contraction of compression wood during drying is associated with these checks.

Considerable functional importance is attached to the altered contents of cell wall constituents, and the altered distribution of these constituents in the walls of compression tracheids as compared with normal tracheids (Timel 1965). It is pointed out particularly that the content of lignin increases.

The present study reports on the occurrence of callose in the walls of compression tracheids. A survey of the occurrence of this substance in the compression wood of available gymnospermous species is presented. 


\section{MATERIAL AND METHODS}

The following 20 species of gymnosperms growing in the Wrocław Botanical Garden have been investigated: Agathis alba, Araucaria bidwillii, Cedrus atlantica and Cupressus macrocarpa all grown in a greenhouse, and Ginkgo biloba, Taxus baccata, Torreya nucifera, Abies concolor, Pseudotsuga taxifolia, Picea excelsa, Larix europaea, Larix polonica, Pinus cembra, Pinus strobus, Tsuga diversifolia, Taxodium distichum, Cryptomeria japonica, Chamaecyparis pisifera, Juniperus communis and Thuja occidentalis growing in the open.

As material for the study side branches aged 3-25 years were collected from trees of different ages. Unfixed, green or dried branches were sectioned free-hand, transversally or longitudinally at a $0-13 \mathrm{~cm}$ distance from the branch base. The sections were stained for fluorescence microscopy according to the callose - aniline blue - fluorescent method (Jensen 1962). A HBO 50 high-pressure mercury vapour lamp was used as illuminator, and BG3/4, having maximum transmissivity at $366 \mathrm{~nm}$, together with GG/9-OGl filters to absorb the visible spectrum and UV light, respectively.

At this UV wavelength self-fluorescence of cell walls was observed. Sections from the same material, but not treated with aniline blue served as control. On most of the transverse sections treated with aniline blue it was possible to observe the fluorescence in the callose of phloem cells, which offered a possibility of comparison of the fluorescence in the walls of compression tracheids with that in the phloem. In a number of species resorcin blue (lacmoid) was employed (Jensen 1962), and solubility tests - the Schweitzer reagent (copper-oxide-ammonia), concentrated $\mathrm{SnCl}_{2}$ and $\mathrm{CaCl}_{2}$ were made for callose.

\section{RESULTS}

A substance which gives yellow fluorescence after treatment with aniline blue similar to that produced by phloem callose, was observed in compression wood tracheids. This fluorescence differs in colour from self-fluorescence of cell walls seen on control sections, and is much stronger than the latter. Tracheids of normal wood do not give this fluorescence after treatment with aniline blue. Resorcin blue in 1:2500 concentration stains compression wood tracheids blue and distinguishes them thus from tracheids of normal wood. The Schweitzer reagent does not weaken the fluorescence, i.e. does not dissolve the substance. After two-week treatment with concentrated $\mathrm{SnCl}_{2}$ and $\mathrm{CaCl}_{2}$ the fluorescence subsides markedly but does not disappear even after four week treatment. On the basis of these tests I consider the substance to be callose.

The distribution of the callose in compression wood is illustrated by photomicrographs of transverse and longitudinal sections of Larix europaea and Pinus strobus. On thin transverse sections callose is seen in the form of fine striae oriented radially in the S2 layer. These striae branch towards the S1 layer (Fig. 1). On longi- 
tudinal sections the callose has the form of fine striae parallel to each other and oriented obliquely, at an angle of about $45^{\circ}$ to the cell axis (Fig. 2, 3). Since there are no breaks in the striae on the longitudinal sections, it can be supposed that they form continuous spirals. In both types of sections the distribution of the striae is similar to that of helical checks well known in compression tracheids from the studies of Core et al. (1961) and Côté (1965).

Callose striae can occur both in early and late compression tracheids. In the latter the callose striae are obviously parallel to pit apertures (Fig. 3), they are, however, not visible in the cell walls over the pit chambers. Neither are they visible over the pit chambers in early tracheids (Fig. 2, 3). A certain accumulation of callose on the edge of the pit apertures is sometimes seen.

Staining with resorcine blue is diffuse, and therefore it does not give a possibility for detailed observation of the distribution of callose in the cell walls.

On somewhat thicker transverse sections, or under low magnification in the microscope. The striae are poorly visible, or invisible, while the whole S2 layer gives a strong yellow fluorescence (Fig. 4, 5, 7).

As a rule, intercellular spaces occur between the compression wood tracheids. If these spaces are prominent enough then on transverse sections they can be seen to be lined with a thin layer of the callose (Fig. 4). In small intercellular spaces callose frequently cannot be observed.

In Larix europaea callose could be observed in all compression tracheids except the earliest and the latest (Fig. 5).

In Pinus strobus callose did not occur in all compression tracheids. On transverse sections from a 4-year-old branch it could be seen in separate rings within the annual ring which on the bottom side was composed of compression wood entirely (Fig. 6). In the subrings without callose which still had all the features of compression wood, single tracheids or whole groups with callose occurred.

In no case was callose found in the walls of cells surrounding the resin ducts (Fig. 7).

Callose in the S2 layer, in the form of striae as described for Larix europaea and Pinus strobus, has been found also in Cedrus atlantica, Cupressus macrocarpa, Abies concolor, Pseudotsuga taxifolia, Picea excelsa, Larix polonica, Pinus cembra, Pinus strobus, Tsuga diversifolia, Taxodium distichum, Cryptomeria japonica, Chamaecyparis pisifera, Juniperus communis and Thuja occidentalis.

Callose has not been found in the compression wood tracheids of Ginkgo biloba, Taxus baccata and Torreya nucifera.

In Agathis alba and Araucaria bidwillii the S2 layer gave on transverse sections a diffuse yellow fluorescence, without visible radial striae. However, on very thin radial sections it was possible to observe very fine short striae forming a dense network. These striae were parallel to each other and oriented at about $45^{\circ}$ to the axis of the cell. 

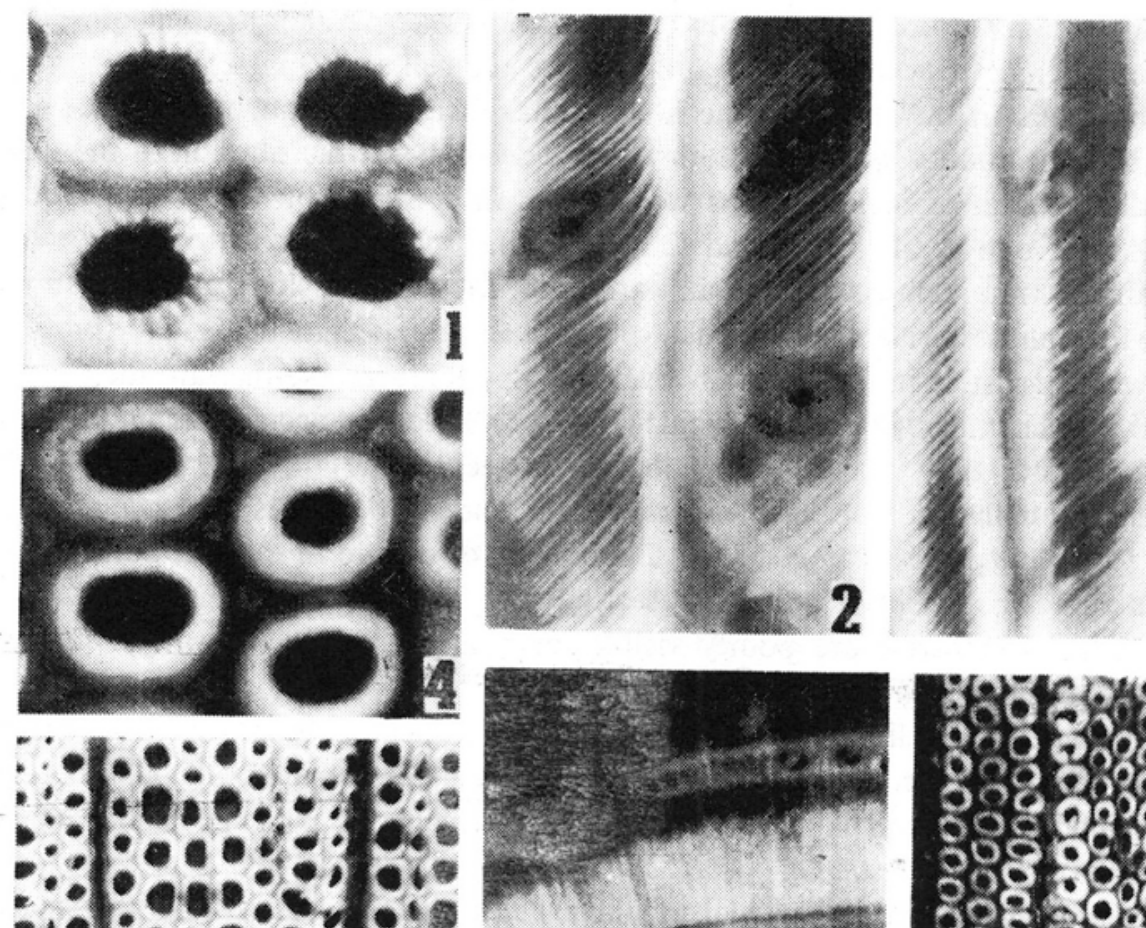

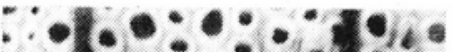

$\because 48$ : $0 . \div \%$

:- e e e

- 10.010

- 1.013

-

- i: a

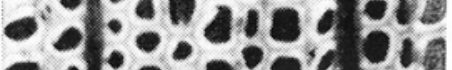

are?

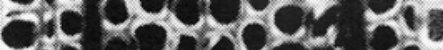

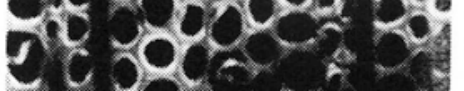
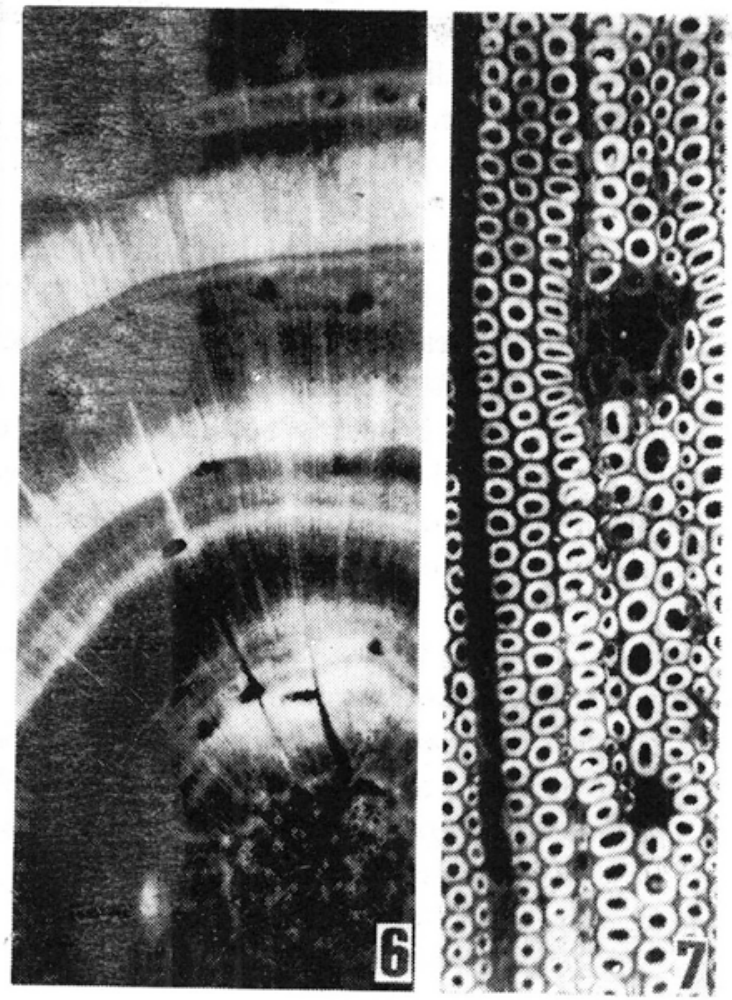

Fig. 1-7. Callose fluorescence (white in the photographs) in compression wood stained with anilineblue. 


\section{DISCUSSION}

The basic methods of identifying callose are based on optical staining, of which the best are the staining with resorcin blue and the fluorescence method with aniline blue which has been introduced in 1949 by Arens and later modified by Currier and Strugger (1955) and Currier (1957). The fluorescence method is belived to be the most sensitive one and most specific for callose. The results of my studies confirm this general belief.

From review papers on callose (Eschrich 1956; Currier 1957, Crafts and Currier 1963) it is known that callose is widely distributed in plants. Crafts and Currier suggest that in appropriate conditions callose can be produced by any active plant cell.

A suplementary criterion for identification of callose is tealived to be solubility tests. There are no objections to the distinction of callose from cellulose on the basis of negative response of callose in the solubility tests with the Schweitzer reagent. However, attempts to dissolve callose in alkalies and in salt solutions are of little use since they give variable results. Frequently callose will not dissolve even after several weeks, besides, its solubility depends to a large extent on the substances with which it occurs. For this reason Eschrich (1956), who made a detailed review of literature informations on the solubility of callose, suggests that callose can be identified on the basis of the colour reaction with resorcin blue and not solubility in the Schweitzer reagent.

From the works of Aspinal and Kessler (1957) and Kessler et al. (1969) we know now, that callose is a $\beta-1,3$-D-glucan and that it is this substance that stains blue with resorcin blue and gives the yellow fluorescence with aniline blue.

Fig. 1. Pinus strobus. Transverse section of compression tracheids with callose visible in the form of radial striae in the S2 layer.

Fig. 2. Larix europaea. Long tudinal section of compression tracheids from early wood. Callose is visible in the form of oblique striae.

Fig. 3. Larix europaea. Longitudinal section of compression tracheids in late wood. Callose is visible in the form of olique striae, parallel to the apetures of bordered pits.

Fig. 4. Larix europaea. Transverse section of compression tracheids with callose in the S2 layer and on the surface of intercellular spaces.

Fig. 5 Larix europaea. Transverse section of compression wood on the boundary between annual rings. It can be seen that in the latest and in the earliest tracheids the amount of callose is very low. Callose does not appear in the ray cells.

Fig. 6. Transverse section of the lower part of Pinus strobus stem with compression wood. In individual annual rings the regions of tracheids with callose are seen to be arranged alternately with regions where the tracheids have little or no callose.

Fig. 7. Larix europaea. Transverse section through late compression wood. It can be seen that callose does not occur in the cells lining resin ducts and in the ray cells. 
It is not known, however, which properties of callose permit a selective absorption of aniline blue, so that the complex produces fluorescence. Thus, further studies are necessary which would answer the question whether in all the described instances we are in fact dealing with the same substance.

The physical properties of callose are still little known, it is, however, certain that callose is a strongly swelling substance. Air dried callose will increase its volume sixfold on imbibition (Eschrich 1965). Since in the compression tracheids callose is localized in helical checks, dehydration during drying may lead to a contraction of compression wood, and hydration may lead to its extension. When compression wood is present in a stem together with normal wood, longitudinal stresses develop.

The magnitude of longitudinal stresses in compression wood is variable. $\mathrm{Hej}$ nowicz (1957) distinguishes active compression wood, if it develops stresses in the stem, and neutral, if it does not. This variability in longitudinal stresses in various types of compression wood can be explained by various contents of callose in the helical checks and various proportions of tracheids with callose in the compression wood.

Formation of compression wood is controlled by hormones (see Westing $1965,1968)$; it is thus possible that also the amount of callose developed in the compression wood tracheids is controlled by hormones. This problem will be studied further.

\section{SUMMARY}

Compression wood from 20 gymnosperms was studied by the fluorescence method following aniline blue treatment. In most trees the existence of callose in the helical checks of the S2 layer of compression tracheids walls has been demonstrated. In Cedrus atlantica, Cupressus macrocarpa, Abies concolor, Pseudotsuga taxifolia, Picea excelsa, Larix europaea, Larix polonica, Pinus cembra, Pinus strobus. Tsuga diversifolia, Taxodium distichum, Cryptomeria japonica, Chamaecyparis pisifera, Juniperus communis and Thuja occidentalis on transverse sections callose occurs in the form of thin radial striae, and on longitudinal sections in the form of long striae oriented at about $45^{\circ}$ to the cell axis. In Agathis alba and Araucaria bidwillii callose occurs in the form of very thin and very sho:t striae, visible only under very high magnification. Callose was pot observed in Ginkgo biloba, Taxus baccata and Torreya nucifera. Since callose is localized in the helical checks of the S2 layer and since it considerably increases its volume during swelling, it is suggested that it plays a role in the generation of longitudinal extension in compression wood.

\section{ACKNOWLEDGEMENT}

The author wishes to thank Prof. dr Z. Hejnowicz for his valuable advice during the performance of the study.

\section{REFERENCES}

Arens K., 1949, Provo de calose por meio da microscopia a luz fluorescente e aplicacoes do metod, Lilloa 18: 71-75.

Aspinall G. O., and Kessler, 1957, Structure of callose from the grape vine, Chem. and Ind. (London) 39: 1296. 
Core H. A., W. A. Côté, Jr., and A. C. Day, 1961, Characteristics of compression wood in some native conifers, Forest Prod. J. 11: 356-362.

Côté W. A. Jr. and A. C. Day, 1965, Anatomy and ultrastructure of reaction wood [In:] W. A. Côté (ed.), Cellular ultrastructure of woody plants, Syracuse Univ. Press.

Crafts A. S., and H. B. Currier, 1963, On sieve tube function, Protoplasma 57: 188-202.

Currier H. B. 1957, Callose substance in plant cells, Amer. Jour. Bot. 44: 478-488.

Eschrich W., 1956, Kallose. Protoplasma 47: 487-530.

Eschrich W., 1965 Physiologie der Siebröhrencallose, Planta (Berl.) 65: 280-300.

Hejnowicz Z., 1967, Some observations on the mechanism of orientation movement of woody stems, Amer. Jour. Bot. 54: 684-689.

Jensen W. A., 1962, Botanical histochemistry, San Francisco and London.

Kessler G., D. S. Feingold, and W. Z. Hassid, 1960, Utilisation of exogenous sugars for biosynthesis of carbohydrates in germinating pollen, Plant Physiol. 35: 505-509.

Münch E., 1938, Statik und Dynamik des schraubigen Baues der Zellwand, besonders des Druckund Zugholzes, Flora (Jena) 132: 357-424.

Timell T. E., 1965, Wood and bark polysaccharides. In W. A. Côté (ed), Cellular ultrastructure of woody plants, Syracuse Univ. Press.

Wardrop A. B., 1965, The formation and function of reaction wood, In W. A. Côté (ed), Cellular ultrastructure of woody plants, Syracuse Univ. Press.

Wardrop A. B. and H. D. Dadswell, 1950, The nature of reaction wood. II. The cell wall organization of compression wood tracheids, Austr. J. Sci. Res., B. 3: 1-13.

Westing A. H., 1965, Formation and function of compression wood in gymnosperms, Bot. Rev. 31(3):381-480.

Westing A. H., 1968, II. Formation and function of compression wood in gymnosperms, Bot. Rev. 34(1):51-78.

\section{Kaloza $w$ cewkach kompresyjnych}

\section{Streszczenie}

Przebadano drewno kompresyjne 20 gatunków nagonasiennych metodą fluorescencyjną z zastosowaniem błękitu anilinowego i u większości $\mathrm{z}$ nich stwierdzono występowanie kalozy w spiralnych szczelinach warstwy S2 ścian cewek kompresyjnych. U Cedrus atlantica, Cupressus macrocarpa, Abies concolor, Pseudotsuga taxifolia, Picea excelsa, Larix europaea, Larix polonica, Pinus cembra, Pinus strobus, Tsuga diversifolia, Taxodium distichum, Cryptomeria jajponica, Chamaecyparis pisifera, Juniperus communis i Thuja occidentalis na przekrojach poprzecznych kaloza występuje w postaci cienkich prążków promienistych, a na przekrojach podłużnych w postaci długich prążków zorientowanych pod kątem około $45^{\circ}$ do osi komórki. U Agathis alba i Araucaria bidwillii kaloza występuje w postaci prążków bardzo cienkich i bardzo krótkich, widocznych dopiero przy dużym powiększeniu mikroskopu. Nie stwierdzono występowania kalozy u Ginkgo biloba, Taxus baccata i Torreya nucifera. Ponieważ kaloza jest rozmieszczona w spiralnych spękaniach warstwy S2 i ponieważ znacznie zwiększa swoją objętość w czasie pęcznienia, sugeruje się, że bierze udział w generowaniu podłużnego rozprężania drewna kompresyjnego. 